P.П.ШМат, аспірант кафедри філософії ЖДУ імені Івана Франка

\title{
ІДЕЯ СПРАВЕДЛИВОСТІ В СОЦІАЛЬНІЙ ФІЛОСОФІЇ
}

Актуальність обраної теми дослідження зумовлена зростанням значущості проблеми справедливості в наш час, що характерно для періодів соціальних криз. Необхідність звернення до теми соціальної справедливості продиктована також поглибленням ціннісної кризи у зв'язку з тим, що колишні ідеали і моральні цінності втрачають минуле значення. Реставрувати традиційні і сприйняти нові ідеали і цінності можливо лише за тієї умови, якщо вони будуть оцінені суспільством як справедливі.

Кожна людина постійно вдається до категорії справедливості, оскільки будь-яке явище розглядає з позицій справедливості чи несправедливості. «Справедливість - це категорія не тільки етична, але й політична. За своїм змістом справедливість означає рівне право всіх членів суспільства на реалізацію всіх своїх здібностей, покликань, можливостей, потреб і інтересів, а також прагнень, готовність і здатність суспільства забезпечити реалізацію цих прав» [4, 295].

Труднощі дослідження названої проблеми в соціальній філософії зумовлені неоднозначним тлумаченням цієї філософської категорії. У різні історичні епохи та періоди часу їі сприймали, а відповідно, і тлумачили залежно від політичних чи соціальних чинників. В історії філософської думки розрізняють відплатну і розподільчу справедливість. Відплатна потребує дотримання відповідності покарання людини за вчинений нею злочин. Така норма зафіксована, зокрема, у висловлюванні: «Життя за життя, око за око, зуб за зуб» (правило тальйону, згідно з яким помста за кривду не має перевищувати завданої шкоди). У даний час за дії відплатної справедливості передбачено кримінальну відповідальність, і такі дії регулюються нормами кримінального права. Розподільча справедливість передбачала однаковий розподіл благ і відповідальності кожному члену спільноти або пропорційний щодо його дій, значущості тощо.

Даній проблемі присвятили чимало досліджень видатні філософи, соціологи, етики як минулого, так і сьогодення (Фрідріх Августін 
фон Хайєк, Джон Ролз, Платон, Арістотель, Ю.М.Муляр, Л.І.Вербицька, О.Г.Коломієць та ін.).

Нашою метою є розгляд ідеї справедливості в соціальній філософiї, зокрема в різні історичні епохи, оскільки суспільство завжди розцінює будь-які соціальні події з позиції справедливості чи несправедливості. Загалом проблематика соціальної справедливості у філософії сягає античної традиції, передусім текстів Платона та Арістотеля.

Мислителі Давнього Сходу, зокрема китайські мудреці Мо-цзи, Мен-цзи, Ян Чжу та ін., витлумачували справедливість як належний стан речей у суспільстві, державі й світі. При цьому наголос поступово переносився ними з розпізнання божественної справедливості (віри в небо) й шанобливого дотримання іiї щодо власних зусиль людей, які повинні в дусі справедливості розв'язувати проблеми суспільного устрою і міжлюдських стосунків. Так, Мо-цзи стверджував: «Небо любить справедливість і ненавидить несправедливість» $[3,194]$.

Давньогрецькі філософи підкреслювали особливу значущість справедливості в житті людини. «Тільки ті люб'язні богам, яким ненависна несправедливість», - стверджував Демокріт [2, 57]. А сама справедливість, на його думку, $є$ дотриманням природи і виконанням свого обов'язку. Справедливість є благо іншого, стверджує Сократ - головний персонаж платонівської «Держави». Добра людина, у якої є гарний настрій, не творитиме несправедливості [5, 17]. Більше того, вважав Сократ (а раніше - піфагорійці), краще постраждати від несправедливості, ніж самому вчиняти несправедливо [5, 16]. Він відкидає міркування тих своїх співбесідників, які вважали, нібито міркування про справедливість і несправедливість - доля слабких, а не сильних і багатих. Адже справедливою може бути як окрема людина, так і держава (i, відповідно, несправедливою).

Багато уваги приділяв аналізу справедливості й видатний мислитель античності Арістотель. На його думку, справедливість може бути двох видів: справедливість від природи і згідно із законом, який встановлює держава. Першу він вважає вищою справедливості згідно із законом, але основну увагу приділяв цивільній справедливості. Бути справедливим - значить виконувати все те, що вимагає закон [2, 463]. А він вимагає бути мужнім, розсудливим та ін. Отже, висновує Арістотель, справедливість $є$ найдосконалішою 
доброчесністю, в якій немовби поєднуються всі інші доброчесності. Вона виявляється, передусім, у відносинах з іншими людьми. Тому початковим іiі принципом є принцип рівності. А несправедливість виявляється в нерівності, коли люди наділяють себе більше, ніж інших, різними добрими речами. Словом, пише античний філософ, «справедливість $є$ якась середина між надмірністю і нестачею» $[2,464]$.

Люди самі неоднакові і діють в різних умовах. Тому суто формальне виконання принципу рівності не завжди може бути справедливим. 3 огляду на це Арістотель запроваджує додатковий принцип - принцип пропорційності: «Якщо справедливе - це рівне, то пропорційно рівне також буде справедливим» [2, 464]. Пропорційна рівність полягає в тому, що ті, хто має велике майно, роблять великий внесок, а ті, хто має мале - малий внесок, той, хто багато попрацював, одержує більше, ніж той, хто попрацював мало, і т.д. Словом, суспільне життя тримається справедливістю, і справедливе - те саме, що й пропорційне. А природна справедливість (пропорційна) полягає в тому, що ліва рука згідно зі справедливістю робить менше, ніж права, дитина - менше, ніж дорослий.

Арістотель та інші мислителі розуміли, що державні закони самі по собі можуть бути недосконалими, несправедливими. Але вони були переконані, що краще виконувати недосконалі закони, ніж жити без законів, бо інакше в суспільстві настане хаос, анархія.

Цінним $є$ й таке зауваження Арістотеля: як справедливі, так i несправедливі вчинки скоюються усвідомлено і доброю волею. Якщо ж індивід вчинить якусь дію через незнання (наприклад, думаючи, що вбиває ворога, насправді вбиває батька), то такого слід вважати не несправедливим, а нещасним.

Наведені нами думки мислителів античності, як і багато інших, стали відправним пунктом розгляду даного явища морального життя в подальші століття. Справедливість припускає і відповідальність суспільства перед особою, яка також має право оцінити громадські порядки в певних ситуаціях як несправедливі. Інакше кажучи, справедливість є міра відповідності між змістом того або іншого вчинку та його оцінюванням громадською думкою.

Розвиток цивілізації, нові виклики людству потребують постійного оновлення концепції справедливості. Не $є$ випадковим те, що вона завжди перебувала в центрі уваги західних філософів, соціологів. Шотландський філософ, історик, економіст, публіцист 
Дейвід Юм (1711-1776) сформулював нову концепцію справедливості, згідно з якою, зміст і критерії принципу справедливості можуть змінюватися в дуже широких межах. Справедливість - доброчесність «штучна» (на відміну, наприклад, від милосердя, яке $\epsilon$ (природним») і передбачає згоду між членами суспільства щодо принципів співжиття. Саме відповідно до цих принципів, котрі $\epsilon$ несталими і можуть змінюватися за згодою членів суспільства, й має вибудовуватися концепція справедливості. Розглядаючи проблему справедливості, вважав Юм, необхідно враховувати ії конкретно-історичний характер. Тому він і розглядав справедливість як штучну чесноту на відміну від інших - природних. Зрозуміло, що конкретно-історичний характер розуміння справедливості потрібно враховувати, проте абсолютизація мінливого характеру розуміння справедливості не виправдана, оскільки призводить до релятивізму чи навіть нігілізму $[8,3]$.

У США проблему справедливості грунтовно досліджував американський соціолог, філософ Джон Ролз (1921-2002). Тезисно розглянемо основні принципи його концепції.

Справедливість, на думку Дж.Ролза, $є$ головною чеснотою суспільних інститутів, подібно до того, як істина є головною чеснотою наукових систем. Якщо теорія хибна, то за будь-яких умов її слід відкинути чи переглянути. Це стосується й державних законів та суспільних інститутів, якщо вони несправедливі. Кожен індивід, за Джоном Ролзом, має право на недоторканність, яку не може ігнорувати навіть найблагополучніше суспільство. Справедливість не допускає й думки про те, що несвобода одних людей може бути виправданням найбільшого розкошування інших, навіть за умови, що останні становлять більшість. Справедливість не сумісна 3 принесенням у жертву інтересів одних людей заради інтересів інших. У справедливому суспільстві рівна свобода громадян розцінєються як щось завчасно встановлене. Щоправда, гарантовані справедливістю права не можуть бути предметом політичних спекуляцій або суто кількісного підрахунку суспільних інтересів. Єдине, що виправдовує застосування хибної теорії, - відсутність кращої. Так само й несправедливість стає терпимою лише тоді, коли вона $\epsilon$ умовою уникнення ще більшої несправедливості.

Обгрунтовуючи своє розуміння принципів справедливості, Ролз зазначає, що суспільство $є$ більшою чи меншою мірою самодостатньою 
спілкою індивідів, які у своїх стосунках визнають певні правила поведінки обов'язковими. I не тільки визнають, а й діють переважно у відповідності з ними. Ці правила визначають систему взаємодії, розраховану на досягнення благ усіма тими, хто бере в ній участь, проте для суспільства однаковою мірою типовість і тотожність інтересів існує доти, поки соціальна взаємодія дає можливість для кращого життя порівняно 3 тим, якби люди жили лише завдяки власним індивідуальним зусиллям. Конфлікт інтересів відбувається тоді, коли індивіди стають небайдужими до більших благ, створених і розподілених ними спільно, оскільки кожний із них віддає перевагу більшим благам. Із різних суспільних устроїв мають бути обрані принципи, які визначали б основи розподілу, що грунтувався б на належних розподільчих відносинах для створення вихідної згоди. Ці принципи є принципами соціальної справедливості, оскільки саме вони забезпечують спосіб визначення прав і обов'язків найважливіших суспільних інститутів. Вони встановлюють також порядок розподілу вигод і тягот суспільної співпраці.

Суспільство, на думку Ролза, тоді добре є організованим, коли воно не тільки створене для надання благ людям, але й коли ефективно саморозвивається завдяки концепції справедливості. У такому суспільстві кожний громадянин знає (і визнає за належне), що всі інші члени суспільства визнають і схвалюють одні й ті самі принципи справедливості. Зважаючи на недоліки принципу рівних можливостей і враховуючи позитивний аспект принципу рівних результатів, Дж.Ролз узяв за основу концепції соціальної справедливості два різних принципи: 1) «Кожна особа повинна мати рівне право на щонайширший план рівних основних свобод, і цей план має бути сумісним із подібною схемою свобод для інших» $[6,60]$. Цей принцип має своєю передумовою рівність у володінні всіма базовими правами. 2) «Соціальні й економічні нерівності слід залагоджувати таким чином, щоб а) можна було розсудково сподіватися на їх корисність для кожного й б) вони пов'язувалися з відкритими для всіх посадами й постами» $[6,60]$. За цим принципом допускається соціальна й економічна нерівність, наприклад, у достатку та владі.

Оцінити реалістичність концепції справедливості Джона Ролза чи спростувати iї здійсненність непросто. Незаперечним $\epsilon$ те, що проблема справедливості ще не розв'язана навіть у найдемократичніших сучасних державах. Нині західні соціологи та етики щиро 
переймаються цією проблемою.

Отже, справедливість - один із принципів, що регулює стосунки людей у сфері розподілу (перерозподілу) як особистих цінностей, так і соціальних (свобода, доходи, можливості навчання та оздоровлення тощо).

Справедливість завжди перебувала в центрі уваги філософів, соціологів під час розгляду людини, як істоти політичної (чи, коректніше було б сказати, «полісної», у розумінні Арістотеля), соціальної, такої, яка не існує ізольовано, тож впливає і сама зазнає впливу, тобто є водночас суб'єктом і об'єктом соціальної дії.

У соціальному аспекті справедливість виступає як формальна рівність, однаковість масштабу (вимог, законів, правил, норм), за допомогою якого «вимірюються» і вчинки людей, що стають у такому разі особами, зрівняними між собою як суб'єкти права. I в моралі, і в праві справедливість виявляється рівністю, але істотно різною. Так, у праві нею буде та діяльність, що найбільше відповідає вимогам закону. Але, оскільки закон, частково дозволами, частково заборонами, прагне втілити в життя всі чесноти, то й справедливість таким чином охоплює всі чесноти, як ціле - частини. Тому розуміння справедливості вимагає дотримання всіх чеснот. Інакше, без дотримання всіх чеснот, iї не буде досягнуто, адже справедливість полягає не у формальній, суто зовнішній відповідності вчинків закону, у дотриманні самого духу і сенсу закону, а в дотриманні закону, як блага. Адже одна справа виконання закону як припису, а інша - виконання закону як блага [7, 88-89].

Моральна (соціальна) справедливість - це, можна сказати, рівність безкінечностей. Люди при цьому рівні так, як можуть бути рівні довершені світи. Правова справедливість, навпаки, є рівністю одиниць, вона цілком укладається в рамки арифметичної рівності, але у певному сенсі тільки іiі і можна вважати рівністю, - люди рівні саме як суб'єкти права, у яких начебто не було інших властивостей, інтересів, потреб, цілей, крім як виконувати норми права. Але сам акт на установлення полягає в легітимації нерівності занять і статусів, що утворюють структуру засновуваного соціального простору (поділ праці, виділення органів керування і т.д.). Проблема полягає в поєднанні рівності і нерівності. Моральна справедливість - теж відповідність між практичною роллю соціальних верств у житті суспільства та їхнім соціальним статусом, між правом і обов'язком, 
вчинком і відплатою, працею і винагородою, злочином і покаранням, між заслугами і суспільним визнанням. Невідповідність у цих співвідношеннях оцінюється як несправедливість, що призводить до дисгармонії індивідуальних і суспільних інтересів і дестабілізації системи соціальних зв'язків [7, 104-105].

Існують два види (форми) справедливості, виокремлені ще Арістотелем. Вони становлять наріжну конструкцію всіх наступних теорій справедливості: розподільна, чи дистрибутивна, справедливість, та, що зрівнює, чи ретрибутивна справедливість $[1,217]$. Вони являють собою способи розподілу благ, яких не вистачає на всіх, хто на них претендує і які взагалі не можуть бути розподілені без того, щоб когось не обділити.

Крім того, Арістотель розрізняв загальну і приватну (спеціальну) справедливість. Під загальною справедливістю він розумів відповідність закону, розумність полісного життя; її можна визначити як загальний моральний знаменник усіх соціально упорядкованих відносин між людьми. Справедливість додає легітимності суспільним діям і формам життя. Вона збігається 3 моральністю в iii проекції на соціальну сферу, відповідає на запитання про призначення і зміст спільного, об'єднаного, соціально упорядкованого існування в суспільстві і державі. У іiі осмисленні склалися дві філософські традиції, за якими стоять різні суспільні практики.

Перша традиція виходить $з$ ідеї кооперації. Диференційоване усередині себе як державно організоване суспільство - щось більше, ніж проста умова виживання і безпечного існування індивідів; воно $\epsilon$ спосіб доброчесного життя, конкретна форма, у якій індивіди можуть реалізувати себе і досягти досконалості. Шлях від природного індивіда до морально-доброчесної особистості лежить через розумно влаштоване співжиття, яке, по-перше, завдяки поділу праці уможливлює існування різних наук і мистецтв, створюючи тим самим предметне середовище для самореалізації індивідів як доброчесних особистостей; по-друге, дозволяє відокремити розумову працю від фізичної, створити дозвілля, що є умовою вільного розгортання внутрішніх сил індивіда, простором людської евдемонії. Держава в іiї адекватних формах (наприклад, поліс для античних авторів, освічена монархія для Гегеля) мислиться як утілений розум, предметне вираження розумності людини. Відповідно благо держави ставиться вище блага окремих індивідів, фактичне гіпостазування 
суспільства, держави як опредметненої справедливості співвіднесене $з$ розумінням того, що гарантією останньої $є$ в кінцевому підсумку індивідуальна чеснота, справедлива особистість. Основна i специфічна риса справедливої особистості складається в безумовному проходженні боргу. Вона керується переконанням «кожному своє» і на його основі не тільки вміє обмежувати себе, але й визнавати першість за іншими завдяки їхнім людським якостям.

Друга традиція обгрунтування справедливості вбачає в суспільстві і державі лише спосіб обмеження, стримування конфліктів, зовнішнє середовище безпечного існування людини. Найбільш повно вона втілилася в концепціях суспільного договору (Джон Локк, Жан-Жак Руссо та ін.). Ці концепції виходять з гіпотези природного стану, у якому індивіди мають необмежену волю, через що вони, взаємно зіштовхуючись, опиняються в ситуації тотальних небезпек. Право на всіх обертається відсутністю якогось права. Держава є розумним виходом $з$ такого стану. Ї̈ призначення полягає в тому, щоб гарантувати безпеку індивідів шляхом взаємоврівноважування їхніх прав. Справедливість держави у цьому випадку виміряються добробутом індивідів. Моральне виправдання держави виявляється одночасно його обмеженням, зведенням до прийнятного для всіх необхідному мінімуму зовнішніх рамок.

У цій традиції справедливість розуміється переважно як об'єктивний принцип, сукупність вимог, найчастіше кодифікованих, здійснення яких гарантується заохоченнями і покараннями. Як інституціолізована сукупність вимог справедливість припускає і формує в індивідах певні суб'єктивні здібності (насамперед здатність випливати нормам), але в ідеалі передбачається, що вона повинна функціонувати незалежно від доброї волі людей.

Оцінити реалістичність концепцій справедливості в різні історичні епохи чи спростувати їх здійсненність непросто. Незаперечним $є$ те, що проблема справедливості ще не розв'язана навіть у найдемократичніших сучасних державах. Нині західні соціологи та етики щиро нею переймаються. Прикладом може бути гуманістична теорія справедливості Дж. Ролза, Фрідріха Августіна фон Хайєка та ін. 3'ясування труднощів реалізації принципу справедливості в державах з ринковою економікою $є$ для нас надзвичайно актуальним, оскільки наша держава перебуває на шляху формування ринкової економічної моделі. Праці науковців, які займаються 
проблемою справедливості, свідчать про те, що вона досі лишається в центрі уваги навіть у найдемократичніших державах світу. В умовах становлення сучасної української держави проблема справедливості набирає виняткової ваги. Необхідною передумовою іiі розв'язання $є$ 3'ясування сутності справедливості в умовах сучасного українського суспільства, а реалізація цієї проблеми залежить від узгодженої роботи трьох гілок влади нашої держави.

\section{ЛІТЕРАТУРА}

1. Арістотель. Нікомахова етика. - К., 2002. - 480 с.

2. Богомолов А.С. Античная философия. - М., 1985. -368 с.

3. Древнекитайская философия. Собрание текстов в двух томах. - T.I. M., 1972. $-363 \mathrm{c}$.

4. 4.Осічнюк Ю.В. Філософія. - К., 2003.- 464 с.

5. Платон. Держава / Пер. 3 давньогр. Д. Коваль. - К., 2000. -355 с.

6. Ролз Дж. Теорія справедливості. - К., 2001. - 822 с.

7. Савельєв В.П. Етика: Навчальний посібник. - 2-ге вид., виправлене. Львів, 2006, - 244 с.

8. Тофтул М.Г., Шмат Р.П. Проблема справедливості: етичний аспект // Вісник ЖДУ ім. І. Франка. Випуск 31. - Житомир, 2007. - С.3-5.

9. Юркевич Памфіл. Історія філософії права; Філософія права; Філософський щоденник. - К., 1999. - 756 с.

Шмат Р.П. Ідея справедливості в сочіальній філософії.

У статті висвітлюються різні погляди на поняття справедливості. Зосереджується увага на неоднозначному тлумаченні цієї філософської категорії. Розглянуто процес реалізації принципів справедливості в різні історичні епохи. При цьому враховується характер політичних і суспільних устроїв. Сфокусовано погляд на основні принципи нових підходів до теоретичного осмислення і практичного втілення принципів справедливості на прикладі концепцій Платона, Арістотеля, Джона Ролза.

Ключові слова: обов'язок, «поліс», справедливість відплатна й розподільча, право, соціальна справедливість, закон.

Шмат Р.П. Идея справедливости в сочиальной философии.

В статье освещаются различные взгляды на понятие справедливости. Сосредотачивается внимание на неоднозначном толковании этой философской категории. Рассмотрен процесс реализации принципов 
справедливости в разные исторические эпохи. При этом учитывается характер политических и общественных устройств. Сфокусирован взгляд на основные принципы новых подходов к теоретическому осмыслению и практическому воплощению принципов справедливости на примере концепций Платона, Аристотеля, Джона Ролза.

Ключевые слова: долг, «полис», справедливость возмездная и распределительная, право, социальная справедливость, закон.

Shmat R.P. Idea of justice in philosophy sotsyalnoy.

The article highlights the different views of justice. Focuses on the interpretation of this ambiguous philosophical category. The process of implementing the principles of justice in different historical periods. This takes into account the nature of the political and social order. View focused on the basic principles of new approaches to theoretical understanding and practical implementation of the principles of justice for example concepts of Aristotle, John Rawls. A parallel between species (forms) equity allocated to Aristotle and principles of social justice declared John Rawls. It is proved that the basis of the concept of social justice Rawls put two principles: the principle of ownership of all basic rights and the principle of affluence and power. It is shown that Aristotle distinguished justice and distributive justice that equalizes.

Key words: debt, «policy» compensatory justice and distribution, law, justice, law. 